\title{
Kimberlites in a Karoo graben of Northern Mozambique: tectonic setting, mineralogy and Rb-Sr geochronology
}

\author{
R.M. Key \\ BGS, Murchison House, West Mains Road, Edinburgh, Scotland EH9 3LA \\ e-mail: rmk@bgs.ac.uk \\ B. Bingen \\ Geological Survey of Norway (NGU), N-7491 Trondheim, Norway \\ e-mail: Bernard.Bingen@NGU.NO \\ E. Barton \\ 12 The Valley Road, Johannesburg 2193, South Africa \\ e-mail: erikabarton@yahoo.com \\ E.X.F. Daudi, S. Manuel, A. Moniz \\ DNG, P O Box 217, Maputo, Mozambique \\ e-mail: edaudi@teledata.mz \\ V. Melezhik \\ Geological Survey of Norway (NGU), N-7491 Trondheim, Norway \\ e-mail: Victor.Melezhik@ngu.no
}

\begin{abstract}
Kimberlites occur as dykes up to $3 \mathrm{~m}$ thick and isometric bodies in the southern explored part of a NE-SW trending Karoo graben across the Mozambique Belt in northern Mozambique. The kimberlites are reported along four NW-SE-trending zones, and one ENE-WSW-trending zone. The kimberlites are macrocrystic hypabyssal Group Ia kimberlites based on their mineralogy and whole rock geochemistry. The kimberlites show a typical crystallization history with early olivine, perovskite, ilmenite and phlogopite growth succeeded by rutile and spinel
\end{abstract}


crystallization. Serpentine and calcite are the youngest primary minerals although there is also secondary growth of these two minerals. Pyrope occurs as rounded xenocrysts. SEM analyses of various macrocrysts and groundmass minerals, as well as $\mathrm{Sr}$ isotope data confirms the Group I classification of these kimberlites. A phlogopite Rb-Sr mineral isochron provides a Lower Cretaceous estimate of $138 \pm 8.5$ Ma for emplacement of one of the isometric body.

The two principal trends of the dykes, together with their absolute age, strongly suggest that their emplacement was controlled by stresses associated with Lower Cretaceous break-up of Gondwana, involving dextral offset of Madagascar with respect to mainland Africa. These stresses reactivated bounding faults to the Karoo graben hosting the kimberlites. Dextral shearing along the bounding faults produced Riedel fractures within the graben that were infilled by kimberlite dykes.

$\mathrm{U}-\mathrm{Pb}$ zircon dates from the crystalline basement of northern Mozambique indicate that the Karoo graben hosting the kimberlites covers a major NNE-SSW trending tectonic boundary in the basement. To the NW of the graben, Palaeoproterozoic ( $>1.95 \mathrm{Ga})$ crust is recorded while Mesoproterozoic $(<1.07 \mathrm{Ga})$ crust is widespread to the SE.

Insufficient mineral-chemistry data is presently available to decide whether the kimberlites are likely to be diamondiferous. The northern Mozambique kimberlites form the NE extremity of a trans-continental NE-SW kimberlite corridor that stretches from southern Namibia across Botswana and central Zimbabwe into northern Mozambique.

\section{Introduction}

Kimberlites were found in northern Mozambique by a group of Soviet geologists in the 1970s (Afonso \& Marques, 1993, quoted in Lächelt, 2004). The kimberlites 
intrude Karoo sedimentary rocks which define a major graben cutting across Proterozoic metamorphic rocks of the Mozambique Belt. The field relationships of the northern Mozambique kimberlites are documented in original reports and maps in Russian. However, accompanying laboratory work is not published, and thus the diamond potential of these kimberlites is largely unknown. Several of the kimberlites were re-sampled in 2003, as part of a regional bedrock-mapping program. The present account summarizes available information on the kimberlites and their geologic setting, and reports new data, including field observations, petrographic data, SEM mineral analyses, and Rb-Sr isotopic data. The objective is to characterize these kimberlites and provide a framework to assess their diamond potential.

\section{Geological setting}

The studied kimberlites are hosted in a ca. 140 x $60 \mathrm{~km}^{2}$, NE-SW tending graben filled with Permian to Jurassic Karoo sedimentary strata in northern Mozambique. The graben is situated immediately to the east of the East African Rift System (Figure 1), and extends to the NE in Tanzania. In the literature, it is variously referred to as the Lunho River Graben, Maniamba Graben or Metangula Graben (Karakoulov, 1983, 1984; Verniers \& others, 1989) in northern Mozambique and the Selous Basin in Tanzania. The Karoo strata include a lower sequence with ‘coal measures’ of Permian age attributed to the Ecca Group. The overlying upper Karoo siliciclastic sediments are of probable upper Permian/Triassic to Jurassic age (Verniers \& others, 1989). The graben system developed by rifting throughout Karoo deposition and is up to about 10 km deep in its centre. Karoo strata dip to the NW in the southernmost part of the graben where Lower Karoo strata are exposed. Elsewhere Upper Karoo strata are exposed. They are flat-lying in the centre of the graben and define a broad NNEtrending anticline in the north (on the north side of the major NW-trending Moola 
River Fault). It has been proposed that the total thickness of the Karoo sequence increases from about $1650 \mathrm{~m}$ in the south to about $6000 \mathrm{~m}$ along the Tanzania border. No extrusive volcanics (of Jurassic age) are preserved at the top of the Karoo sequence in contrast to the voluminous flood basalts that cap Karoo successions further to the south throughout southern Africa.

The Karoo graben overlies Proterozoic rocks of the Mozambique belt. Investigations in progress suggests that the two shoulders of the Karoo graben are distinct, and consequently that the graben covers a major Pan-African or older lithospheric boundary.

To the NW of the graben, the Ponta Messuli gneiss complex (outcropping along the shores of Lake Niassa) is associated with metasedimentary rocks of the Txitonga group. An amphibolite-facies migmatitic paragneiss from the Ponta Messuli Complex contains detrital zircon cores ranging in age between 2.20 and $1.99 \mathrm{Ga}$ and metamorphic zircon overgrowths dated between 1.98 and 1.95 Ga (unpublished SIMS data). U-Pb dating of monazite in this sample (unpublished LA-ICPMS data) constrains the timing of migmatitization at $1954 \pm 15$ Ma. Available zircon and monazite data demonstrate that the Ponta Messuli complex contains a basement older that $1.95 \mathrm{Ga}$ affected by an amphibolite-facies overprint at $1.95 \mathrm{Ga}$. The data suggests that the Ponta Messuli complex forms an extension of the Palaeoproterozoic Usangaran belt of Tanzania. Whole-rock Sm-Nd isotopic data are available on three samples from the Ponta Messuli complex (Saranga, 2004). The samples are garnetbiotite gneiss, biotite-epidote gneiss and a charnockite, mapped by the authors as part of units of amphibolite and granitic gneiss. The three samples yield Archaean depleted mantle model ages ( $\mathrm{T}_{\mathrm{DM}}$ ) ranging from 3.01 to $2.64 \mathrm{Ga}$. The data indicate that the extraction of the protoliths to these gneisses from the depleted mantle took 
place during the Archaean. The data suggest the presence of an Archaean crustal component in the crust forming the Ponta Messuli complex (sedimentary material or magmatic basement).

To the SE of the Karoo graben, the Unango complex consists mainly of granitic and charnockitic orthogneisses formed between 1.07 and $0.99 \mathrm{Ga}$. These gneisses are intruded by $0.80 \mathrm{Ga}$ alkaline granite and Pan-African plutons. The Unango complex is affected by Pan-African high-grade metamorphism, though this metamorphism is poorly dated as of today.

\section{Previous studies on the Kimberlites}

Oberreuter \& Pilale (1998) provide an overview after Stajilo-Alekseev (1983) of the diamond exploration work undertaken by Soviet geologists in the late 1970s and early 1980s in the NW part of Niassa Province. The first kimberlite was discovered in 1979 at Lufutiche by Jakovenko \& others (1979). These workers estimated that the area with potential for kimberlites covered about $1100 \mathrm{~km}^{2}$ in the basins of the rivers Lunho, Fúgòe, Luile and Chissongo. Another 43 kimberlite dykes, as well as an unknown number of kimberlites and 4 isometric bodies (diatremes or pipes) were subsequently discovered in the SW part of the Karoo graben in the basins of the Lunho and Fúgòe rivers. As of today, the remainder of the graben remains unexplored for kimberlites. Following Oberreuter \& Pilale (1998), brecciated kimberlites were not found as dykes but confined to pipes. The kimberlites are associated with low (positive and negative) magnetic anomalies. No kimberlites were found in the Proterozoic basement surrounding the Karoo graben. An investigation of stream sediments in the basement areas also failed to uncover any kimberlite indicator minerals. Available reports therefore concluded that there was a direct link between the formation of the graben and the emplacement of the kimberlites. A comparison 
was made between the kimberlite occurrences in northern Mozambique and kimberlites in northern Tanzania, confined to the Ruhuhu Graben within the East African Rift System (McKinlay, 1955).

Five zones with kimberlites were identified in northern Mozambique, labelled 1 to 5 from west to east (Fig. 2). The three westerly zones (1-3) have parallel NW-SE trends. These are the 'Lefululutxe- Fúgòe Rivers' Zone (1), the 'Upper course of the Fúgòe River' Zone (2) and the 'Tulo-Namango Rivers' Zone (3). The fourth zone, called the 'Luimba River' Zone is short and trends ENE-WSW. The fifth zone, called the 'Micuela' zone is the shortest. It trends NW-SE and is situated directly to the east of zone 4. Kimberlite dykes within each zone trend parallel to the trend of the zones.

The 'Lefululutxe- Fúgòe Rivers' Zone (1) is located between 4 and $10 \mathrm{~km}$ east of Lake Niassa and is about $28 \mathrm{~km}$ long and about $5 \mathrm{~km}$ wide with a trend of 145-325. Nine dykes were identified as well as a kimberlite lode with the biggest dyke on the left side of the Lefululutxe River. Ground investigations were curtailed due to security problems.

The 'Upper course of the Fúgòe River' Zone (2) is narrow (1-2.5 km wide) and was only traced for $12 \mathrm{~km}$. It nevertheless probably continues towards the north out of the area studied by the Soviet geologists. Eleven dykes were found but no detailed ground studies were completed.

The 'Tulo-Namango Rivers' Zone (3) was traced for 25km NW from the southern edge of the graben and is about $4 \mathrm{~km}$ in width across the Lunho River valley. Nineteen dykes and 4 isometric bodies were discovered. The 4 isometric bodies were found along the Namango River valley in the only area prospected in any detail. One isometric body ('TX3' Pipe) underwent detailed magnetic studies and a 1:500 scale map of its outcrop was produced. 
The 'Luimba River' Zone (4) is ca. $500 \mathrm{~m}$ wide and trends $065-245^{\circ}$ for about $2.5 \mathrm{~km}$. Four very thin subvertical dykes were discovered.

The 'Micuela' Zone (5) was followed by ground magnetic surveys for about $600 \mathrm{~m}$ in a $140 / 150^{\circ}-320 / 330^{\circ}$ direction with a width of $200 \mathrm{~m}$. Kimberlites were found in this zone, which is thought to be larger than suggested by the initial surveys.

Most kimberlite dykes are up to $3 \mathrm{~m}$ in thickness but can be $15 \mathrm{~m}$ thick. The dykes of the 'Luimba River Zone' (4) are the thinnest $(<0.2 \mathrm{~m})$. The TX3 pipe of the 'TuloNamango Rivers Zone' (3) is about 60 by $70 \mathrm{~m}^{2}$ in cross section. There is a large block of thermally metamorphosed Karoo strata in the centre of the pipe. Adjacent kimberlite pipes are circular to elongate (e.g. with ca. 15 x $60 \mathrm{~m}^{2}$ cross sections). Kimberlite dykes are locally displaced (up to 50m) by NE-trending faults. The dykes are mostly subvertical although dips as low as $65^{\circ}$ were recorded.

Jakovenko \& others $(, 1979)$ suggested that about $1500 \mathrm{~m}$ of erosion took place in the Namango River region based on the attenuated (lower) Karoo sequence of only 150m in total thickness. They suggested that this erosion affected the kimberlites so that only their roots are preserved. This would imply that the kimberlites are of Karoo or immediate post-Karoo age. An overview map at a scale of 1:125000 prepared by the Soviet geologists shows kimberlite dykes cutting through the entire Karoo sequence, implying that the dykes post-date deposition of all of the Karoo sedimentary rocks. However, Lächelt (2004) records various kimberlitic minerals (pyrope garnet, Mgmagnetite, Mg-ilmenite as well as fragmented diamonds in the basal conglomerates (K7 unit) of the upper Karoo. This observation implies that there are pre-upper Karoo kimberlites within the graben. It is therefore possible that more than one generation of kimberlite dykes is present in the graben. 
The primary surveyors noted that more kimberlites are likely to be found outside of the investigated area within the graben structure. Prospective areas include the northern sides of the Lunho and Fúgòe rivers and the Messinge River basin where indicator minerals have been found. They suggested that the amount of erosion decreases towards the source of the Messinge River where there is a better chance of finding less eroded (and therefore larger) kimberlite pipes.

Olivine, phlogopite, perovskite, serpentine, carbonate, monazite, and traces of pyrope garnet are the main indicator mineral phases recorded in the stream sediments. Pyrope occurs as pale (low chrome) to dark (high chrome) violet grains. Brecciated kimberlite pipes are associated with the largest number of indicator minerals (60\% contain pyrope) and magnetite-bearing kimberlites have the lowest number of indicator minerals. Lithic as well as crystal (olivine, garnet and picrite-ilmenite) clasts are set in a matrix of serpentine and carbonate with sodalite, perovskite and chromediopside.

The exploration area was divided into the following three sub-areas based on the results of panning in the streams,

- Upper courses of the Lucumba and Mecondece rivers with samples characterised by ilmenite-zircon-rutile assemblages with minor clinopyroxene, almandine, tourmalines, epidote and apatite.

- Fúgòe River Basin and right margin of the Lunho River with samples characterised by pyrope-almandine-ilmenite assemblages with minor rutile, zircon, clinopyroxene, limonite and hornblende.

- Left margin of the Lunho River with samples characterised by ilmenitelimonite-almandine assemblages with minor clinopyroxene, zircon, hornblende etc. 
Oberreuter \& Pilale (1998) noted that there are a number of discrepancies and omissions in the three original reports prepared between 1979 and 1983 for the Mozambique Geological Survey Department (DNG). In particular no results were given for the analyses of most of the 5000+ pan and geochemical samples. Most of the detailed (1:500) maps reporting geophysical surveys were not provided. It is therefore not clear as to whether the Soviet geologists found any diamonds.

\section{New results}

\section{Fieldwork}

The kimberlite pipe TX3 from the 'Tulo-Namango Rivers' Zone (3) was accurately located between UTM (wGS84) grid reference 36L 07195378610862 and 0719493 8610891. Four other trenches across minor kimberlite dykes close to TX3 were also examined (e.g. at 36L 07179468613395 and 36L 0719490 8610422). Two near vertical, khaki green, weathered kimberlitic dykes were also observed in a small road cut on the main road to Cobue (36L 0714109 8617410). These dykes are 0.1-0.2 m and $0.8 \mathrm{~m}$ in thickness. They are separated by a thin screen of baked sedimentary rock (mudstones from the Beaufort Group). The dykes’ trend about $054^{\circ}$ i.e. at right angles to the main dyke trend in 'Tulo-Namango Rivers' Zone (3), and it is possible that the dykes represent a south-westerly continuation of the 'Luimba River' Zone (4) (Figure 2).

At the site of kimberlite TX3, several exploration pits with diameters of about $1 \mathrm{~m}$ and depths of several metres are still open. Adjacent spoil heaps display fresh, massive, blue-black (with a faint green tint) kimberlite with mm-thick weathered rinds that vary from dull grey to blue-grey in colour (Plates 1 and 2). All of the examined kimberlites are weakly magnetic with kappameter readings between 9 and $12 \times 10^{-3} \mathrm{SI}$ units. Fresh kimberlite is overlain by pale yellow clayey soil between 1 and $2 \mathrm{~m}$ thick. 
An uppermost veneer of impure grey calcrete over TX3 forms a slightly elevated mound above surrounding Karoo sandstone outcrop.

Large crystals (macrocrysts) up to about $1 \mathrm{~cm}$ in length of olivine (common), garnet, phlogopite, diopside, magnetite, calcite and ilmenite are noted in the TX3 kimberlites in a fine-grained matrix. Olivine and garnet grains have rounded outlines and commonly have very fine-grained alteration rims up to about $1 \mathrm{~mm}$ in thickness. Garnet varies in colour from a very dark red to orange to pale purple and all with a glassy aspect. Olivine grains are variably altered to serpentine. Calcite occurs interstitially in the kimberlite matrix and also as individual large grains or as clusters of large grains. Some of this rhombic carbonate may be dolomite.

The amount of country rock xenoliths is highly variable, although the majority of examined rocks from the spoil heaps are clast deficient. The most common exotic components noted in the field are angular clasts of indurated Karoo sedimentary strata up to several centimetres in length, and angular to rounded quartz grains. The studied kimberlites intrude into well-exposed essentially horizontal sandstone of the Ecca Group (lower Karoo). Abandoned core from a borehole drilled into lower Karoo strata several kilometres from TX3 (at GR 0717644 8613912) was found during the fieldwork. Thinly interbedded arkosic sandstones, siltstones, quartz-pebble conglomerates and carbonaceous mudstones comprise the core and this sequence is interpreted as fluviatile in origin.

\section{Methods}

Five kimberlite samples were analysed at the Geological Survey of Norway including whole rock analyses by XRF on 4 samples (Table 1). Petrographic studies, performed with optical microscopy and a scanning electron microscope (SEM) coupled with an energy dispersive X-ray spectrometer (EDS) were undertaken on nine polished thin 
sections of the 5 kimberlite samples. Rb-Sr isotopic data on phlogopite separates were performed. The Rb-Sr data provides more precise information on the emplacement age of the kimberlites.

\section{Petrography}

The examined rocks are all Group 1 macrocrystic hypabyssal kimberlites with inequigranular textures. Olivine is the dominant primary macrocrystic phase with isolated Mg-ilmenite, pyrope and phlogopite macrocrysts. The groundmass comprises intergrown primary calcite and serpentine with ubiquitous olivine grains and disseminated opaques with common phlogopite and traces of apatite and clinopyroxene. SEM data shows that the opaques comprise perovskite, ilmenite (including Mg-ilmenite) and various spinels including chromite and magnetite. Nickel sulphides (millerite and nickeliferous pyrrhotite) form clusters of (exsolved) acicular grains as inclusions in the macrocrysts. Enstatite forms rare rounded inclusions in Mg-ilmenite macrocrysts. Barium and strontium sulphate/carbonate are 'late' replacement minerals identified by the SEM analyses.

Olivine grains vary from rounded, strongly fractured macrocrysts with embayed margins to small, unfractured euhedral grains in the groundmass. Serpentine infill cracks in olivine macrocrysts and also forms corona structures (with calcite and opaques) around individual grains. Olivine grains remain unaltered away from the serpentine infilled cracks. The macrocrysts are variably replaced (even in a single thin section) by both calcite and serpentine with tiny sulphide needles, and in extreme cases are completely pseudomorphed.

Modal amount of phlogopite is highly variable. Phlogopite occurs as corroded macrocrysts, as well as more common small, embayed and corroded flakes in the groundmass. Rounded and fresh (but internally fractured) pyrope macrocrysts have 
thin alteration (kelyphitic) coronas with an innermost, very thin layer (see SEM data,) and an outer dark layer with finely disseminated opaques. The garnet macrocrysts are embayed and are clearly not in equilibrium with the enclosing groundmass i.e. they are xenocrysts. Internal cracks are partly infilled by 'late' mineral phases that include carbonates and sulphates.

Small olivine grains, carbonate (probably calcite), serpentine and disseminated opaques with variable amounts of tiny phlogopite flakes form a fine-grained groundmass. Euhedral carbonate rhombs (? calcite and/or dolomite) are locally present, as are irregular patches (? amygdales) of calcite in serpentine and calcite veinlets. Some calcitic segregations in the groundmass are cored by an unidentified yellowish, cryptocrystalline mineral (serpophite?). Spinels, ilmenite and perovskite are very common as equant grains with a bimodal grain size distribution. Perovskite grains in the groundmass are embayed with thin alteration rims.

Lithic (mostly sandstone) clasts are strongly indurated and locally replaced by calcite and serpentine. A relict trachytic texture was noted in one clast and an oval-shaped clast has a fern-like internal texture defined by radiating olivine grains from a central 'stem'. The texture may be a fragment of a spinifex fabric within a mantle-derived xenolith. Whole rock chemical analysis of one kimberlite sample (31990 in Table 1) that contains indurated sandstone clasts indicates considerable contamination probably due to assimilation of country rock material into the kimberlite.

\section{SEM petrology data}

Examined garnet macrocrysts (Plate 3) have well-defined outer alteration (kelyphitic) rims that are about $200 \mu \mathrm{m}$ thick. Internal fractures are partly infilled by barium sulphate. Oval shaped millerite inclusions in garnet are about $50 \mu \mathrm{m}$ long and nickeliferous pyrrhotite forms tiny needles. A very narrow strip (ca. 5-10 $\mu \mathrm{m}$ ) of 
strontium sulphate and calcite was identified along the edge of one garnet macrocryst. A similarly narrow strip of barium sulphate was identified between a garnet xenocryst and its kelyphitic corona. Barium sulphate also occur as tiny grains in the groundmass.

Spinels and perovskite grains are typically about $50 \mu \mathrm{m}$ in diameter. Perovskite grains are rounded and embayed and replaced by rims of ilmenite with outermost rutile rinds. The centre of altered perovskite grains is commonly infilled by calcite aggregates with or without rutile. Chromite forms tiny grains cutting into the margins of altered perovskite grains as well as embayed (frayed) cubes and embayed elongate laths with strongly fractured rims of less Cr-rich spinel. All spinels, including Timagnetite, occur as tiny cubes that commonly amalgamate, as well as more ragged grains.

Ilmenite forms embayed, subhedral laths with strongly fractured spinel rims. Mgilmenite forms macrocrysts with very narrow alteration rims with rutile. A dropshaped inclusion of enstatite was found in one Mg-ilmenite xenocryst. Apatite forms embayed subhedral laths, locally with inclusion of Ca-ilmenite.

\section{Crystallization history}

The examined rocks are all Group 1 macrocrystic hypabyssal kimberlites with inequigranular textures. Macrocrysts noted in thin sections are mostly olivine with isolated Mg-ilmenite, pyrope and phlogopite. The garnets are xenocrysts although it is not clear whether the olivine macrocrysts are early primary (cognate) kimberlitic minerals or xenocrysts. However, at least some of the groundmass olivine is an early crystallization phase of the kimberlite magma. Some olivine macrocrysts have angular shapes to suggest that they are fragments of larger megacrysts. 
Opaque minerals appear to have crystallised at different stages with embayed and altered 'early’ perovskite and ilmenite grains and 'late' spinel grains. Alteration rims around perovskite grains formed during resorption in the latest stages of magma crystallization and typically include rutile (Mitchell, 1986). Phlogopite also appears to have crystallised at different stages with embayed 'early' flakes and 'late' poikilitic flakes with inclusions of other minerals including spinel.

Serpentine and calcite are the youngest primary phases and variably replace olivine. They are interpreted as mostly 'late stage' primary kimberlite minerals (equivalent to glass in more felsic magmatic rocks i.e. residual liquid crystallization products) as opposed to secondary alteration phases. However, there is also the possibility that some carbonate, especially in strongly altered samples (e.g. 31990) is secondary and related to groundwater infiltration. Barium and strontium sulphate/carbonate are 'late' replacement minerals identified by the SEM analyses. This sequence of mineral crystallization accords with the typical crystallization history for kimberlites recorded by Mitchell (1986)

\section{Reconnaissance SEM chemistry results}

Selected partial mineral analyses performed with SEM + EDS are reported in Tables 2 to 5 inclusively. Very little zoning was noted in any of the analysed grains.

Pyrope garnets (Table 3) plot in the G9 (lherzolitic) garnet field on the classical $\mathrm{Cr}_{2} \mathrm{O}_{3}$ against $\mathrm{CaO}$ diagram (Figure 4; Gurney \& Zweistra, 1995). The retrograde kelyphitic rims as seen in the present study around garnet xenocrysts (provide minimum PT conditions for garnet growth) and typically form at temperatures of between 900 and $1300^{\circ} \mathrm{C}$ at $10-12$ Kbars according to Garvie \& Robinson (1982). An even higher temperature of formation of the garnets is indicated by their $\mathrm{NiO}$ values of up to $0.036 \%$ with a mean of $0.014 \%(110 \mathrm{ppm} \mathrm{Ni})$. This mean value indicates formation 
temperatures of about $1350^{\circ} \mathrm{C}$ using the nickel thermometer in Ryan \& Griffin (1996). However, lower temperatures of between about 800 and $950{ }^{\circ} \mathrm{C}$ are indicated by plotting the garnet's mean chrome content (5-6 \%) on the Ryan \& Griffin (1996) chrome against nickel thermometer, using the geotherm for Group 1 Kaapvaal Craton kimberlites. This would suggest that there were different (higher) geothermal gradients during Group 1 kimberlite emplacement in the Mozambique Belt than into the Kaapvaal Craton. Nyblade \& Brazier (2002) show that the thick depleted lithospheric mantle underneath the Tanzania Craton does not extend under the Mozambique Belt. This observation strongly suggests higher geothermal gradients under this belt and under adjacent cratons.

A range of spinels is present in the kimberlites based on the SEM data (Figure 6) although all occur as tiny grains in the groundmass. Chromites plot outside of the field of chromite inclusions in diamonds, but do overlap with the chromites associated with the Argyle lamproite field of northern Australia (Figure 5). It is accepted that chromites with more than $60 \% \mathrm{Cr}_{2} \mathrm{O}_{3}$ are associated with diamondiferous kimberlites. The maximum chrome content of the (five) analysed chromites from the northern Mozambique kimberlites is $55.62 \%$ (Figure 5).

Analysed olivine grains are fosteritic with over $45 \% \mathrm{MgO}$ and less than $14 \%$ total iron as FeO (Figure 7 and Table 2). The single analysis of a groundmass clinopyroxene is typical of the 'pure' diopside found in kimberlite groundmasses, as recorded by Mitchell (1986). The very high Ca but low $\mathrm{Al}, \mathrm{Cr}$ and $\mathrm{Na}$ contents distinguish these clinopyroxene grains from clinopyroxene megacrysts. Similarly the single orthopyroxene analysis is closest to those for the Ti-bronzites found as megacrysts in kimberlite or intergrown with ilmenite (Mitchell, 1986). Mica analyses (Table 4) show a range from phlogopite $\left(9-10 \% \mathrm{~K}_{2} \mathrm{O}, 6-7 \% \mathrm{FeO}\right)$ to hydro-phlogopite 
with low $\mathrm{K}_{2} \mathrm{O}$ (8.4\%) and totals (88 wt\%). Also present in 31990 is hydro-biotite ( $\mathrm{K}_{2} \mathrm{O} 3 \%$, FeO 16.9\%), possibly xenocrystal.

\section{Whole rock geochemistry}

Whole rock analyses were completed on 4 kimberlite samples from northern Mozambique (Table 1). Three of the analysed rocks are uncontaminated (based on the Contamination Index of Clement, 1982). The fourth has a high C.I. but this is due to a high calcite content and thereby low MgO content. The whole rock geochemistry from the three uncontaminated samples confirms the petrographic conclusion that they belong to Group I kimberlites, and probably part of Subgroup Ia (Smith \& others, 1985). For example, the analyses plot in the field of Group I kimberlites on plots of $\mathrm{TiO}_{2}$ vs. $\mathrm{K}_{2} \mathrm{O}$ and $\mathrm{Pb}$ vs. $\mathrm{SiO}_{2}$ (Smith \& others, 1985), and $\mathrm{SiO}_{2}$ vs. $\mathrm{MgO}$ (Skinner, 1989) with $\mathrm{Al}_{2} \mathrm{O}_{3}, \mathrm{Fe}_{2} \mathrm{O}_{3}, \mathrm{MgO}, \mathrm{Sr}, \mathrm{Rb}, \mathrm{Th}, \mathrm{Cr}, \mathrm{Zn}$ and $\mathrm{Cu}$ values comparable to Subgroup Ia kimberlites. Only the light REEs were analysed and these show typical kimberlite patterns when plotted on a chondrite normalized REE (Masuda-Coryell) diagram with enhanced values for the Rb to La elements and depleted values for the Ce to Y elements (Smith \& others, 1985).

$\mathrm{K}_{2} \mathrm{O}$ contents of up to $1.58 \%$ are typical for kimberlites but low for other types of ultramafic rocks (Table 1; Dawson, 1980, Table 6; Kirkley \& others, 1991; Mitchell, 1986). Conversely the $\mathrm{SiO}_{2}$ values of between 27 and 30\% for the least carbonated samples are very low for ultramafic rocks but typical for uncontaminated kimberlites $\left(25-35 \% \mathrm{SiO}_{2}\right)$. The potassium contents of the northern Mozambique kimberlites are higher than kimberlite analyses shown in Mitchell (1986) but other elements fall within the range of kimberlite values quoted by Mitchell (1986). High $\mathrm{TiO}_{2}$, Fe oxide and $\mathrm{V}_{2} \mathrm{O}_{5}$ in all of the analysed kimberlites reflect the common presence of spinels, ilmenite and perovskite. Similarly high values of $\mathrm{K}_{2} \mathrm{O}, \mathrm{Al}_{2} \mathrm{O}_{3}, \mathrm{Rb}$ and $\mathrm{Sr}$ are all linked 
to the common presence of phlogopite. Nickel values fall within the 710-1600ppm range for kimberlite (Dawson, 1980, Table 8) and nickel-bearing sulphide needles (including exsolved needle clusters) were detected during the SEM analyses. High barium and strontium values can be explained by the presence of sulphate and carbonate rims around some macrocrysts. Cerium is highest in sample 31991, correlating with high phosphorus values due to relatively abundant tiny apatite laths in the sample.

Smith \& others (1985) conclude that the geochemical signature of Group I kimberlites suggests that they had an asthenospheric-like source in contrast to Group II kimberlites that are inferred to have originated from sources within ancient stabilized subcontinental lithosphere (i.e. Archaean cratons). This would accord with the tectonic setting of the northern Mozambique kimberlites that are set within a rift into Proterozoic crust.

\section{Rb-Sr geochronology and other isotope studies}

Rb-Sr analyses of phlogopites separated from one sample of the TX3 kimberlite (Plate 4) yield an isochron age of $138 \pm 9$ Ma (Figure 8), i.e. in the Lower Cretaceous. The isochron has an MSWD of 8.5 and an initial ${ }^{87} \mathrm{Sr} /{ }^{86} \mathrm{Sr}$ ratio of $0.7052 \pm 0.0026$. This age is interpreted as the time of closure/crystallization of the phlogopite synchronous with the emplacement of the kimberlite.

$\mathrm{C}$ and $\mathrm{O}$ isotope values from carbonate from the studied kimberlites are typical mantle values. The values are as follows: $\delta^{13} \mathrm{C}=-7.8$ per mill vs. $\mathrm{V}-\mathrm{PDB}, \delta^{18} \mathrm{O}=13.8$ per mill vs. V-SMOW 


\section{Discussion}

\section{Structural controls on Kimberlite intrusion}

Kimberlite dykes and isometric bodies are reported in, and only in, the SW-NE trending Karoo graben in northern Mozambique. The Karoo graben straddles a major lithospheric boundary, with Palaeoproterozoic (1.95 Ga and older) crust to the NW of the graben and Mesoproterozoic crust (1.07 Ga and younger) to the SE. Sedimentation in the Karoo graben took place between the Permian and Jurassic. The Lower Cretaceous age obtained for one of the isometric kimberlite body is thus consistent with occurrence of kimberlites crosscutting the entire Karoo sequence.

White \& others (1995) review the structural controls on the emplacement of kimberlites worldwide. They note a relation between kimberlites and extensional faulting in major grabens. Linear grabens above deep-seated mobile belts are highlighted as one of two structural settings favoured by Mesozoic and younger kimberlites. A detailed study of the Lucapa Corridor in Angola shows that kimberlite emplacement is controlled, within the rift system by faults with Riedel geometry (De Boorder, 1982).

A similar model can be applied to kimberlites within the Karoo graben of northern Mozambique. Most kimberlites dykes (Figure 2) trend NW-SE (135-315), and less commonly ENE-WSW (065-245 $)$ within the NE-SW $\left(026-206^{\circ}\right)$ trending graben. Normal displacements on the graben boundary faults controlled Karoo sedimentation and clearly preceded emplacement of the kimberlites. We suggest that post-Karoo stresses caused subsequent dextral offset along these faults and created the extensional fractures infilled by the kimberlites. The NW trending dykes infill conjugate R2-fractures to the major bounding faults and the ENE dykes infill R1shears to the SE margin of the graben (Ramsay \& Huber, 1987). Support for this 
model is provided by figure 2 of plate 2 in Cloos (1955). This figure shows extensional fractures within a dextral shear system that exactly mimic the kimberlitefilled fracture pattern in the Karoo graben of northern Mozambique. The $138 \pm 8.5 \mathrm{Ma}$ age estimate for kimberlites intrusion suggests that stresses related to Lower Cretaceous fragmentation of Gondwana (that effectively isolated Africa as a separate continent) caused re-activation of the bounding faults to the Karoo graben (Jelsma \& others, 2004). The dextral reactivation of the Karoo graben was contemporaneous with dextral offset of Madagascar with respect to mainland Africa during early fragmentation of Gondwana (Jelsma \& others, 2004). Extensional reactivation of these older fundamental faults provided access for upper mantle magmas into the upper crust along second order fractures. Previously, Boyd (1973) as well as Nixon \& Boyd (1973) had suggested that stresses related to Gondwana break-up influenced kimberlite emplacement into the Kaapvaal Craton.

NNE-trending faults of the East African Rift System, which include Lake Niassa (Delvaux, 2001), truncate the western part of the Karoo graben in Northern Mozambique (Figure 1). The western arm of the East African Rift System began to develop at between 12 and 10 Ma (Nyblade \& Brazier, 2002). The East African Rift System thus largely post-dates kimberlite emplacement. Previously, Mitchell (1986) has dismissed any suggestion that emplacement of kimberlites adjacent to the East African Rift System to the north of northern Mozambique in Tanzania was influenced by this Neogene rift system. He also noted that the Neogene rifting post-dates kimberlite emplacement. The fact that the kimberlites are found in the older rifts and not in the East Africa Rift System is a typical feature of east African geology (McKinlay, 1955; Dawson, 1980; Mitchell, 1986). Pre-rift kimberlite pipes were also 
emplaced into Archaean crust within and west of the East African Rift System in northern Tanzania between 53 and 40 Ma (Ebinger \& others, 1997).

Vearncombe \& Vearncombe (2002) concluded from a spatial analysis of kimberlite distribution in southern Africa that kimberlites are intruded in corridors next to, but not along prominent shears and crustal faults. They noted that kimberlites have to be emplaced into relatively homogeneous, strong lithosphere capable of sustaining the very high $\mathrm{CO}_{2}$ pressure necessary for the rapid emplacement of kimberlites. Previously Dawson (1980) and Crockett \& Mason (1968) had noted that kimberlites in the Kaapvaal Craton follow fractures, including a NE-SW set, that cut across preexisting bedrock structures.

Confirmation of the Vearncombes' statistical analysis of kimberlite distribution in southern Africa has recently been given by Jelsma \& others (2004) who analysed a much larger data set. They noted several major kimberlite corridors including a NESW corridor of kimberlites across southern Africa from southern Namibia across Botswana into central Zimbabwe. The northern Mozambique kimberlites form a NE continuation of this corridor that is now a trans-continental structure (Figure 3).

\section{Conclusions and diamond potential of the kimberlites}

1. The presence of kimberlite dykes and diatremes has been confirmed in northern Mozambique and an accurate location pinpointed for the largest diatreme found during the original prospecting by Soviet geologists.

2. It is now established that the host NE-SW Karoo graben to the kimberlites cuts across a major NNE-SSW tectonic break in the underlying basement. A western Palaeoproterozoic terrane with indications of Archaean protoliths is separated from an eastern terrane that is no older than about 1.07Ga. 
3. The kimberlites are macrocrystic hypabyssal Group Ia kimberlites based on their mineralogy and whole rock geochemistry.

4. SEM analyses of various macrocrysts and groundmass minerals, as well as $\mathrm{Sr}$ isotope data confirms the Group I classification of these kimberlites.

5. A phlogopite Rb-Sr mineral isochron provides a Lower Cretaceous estimate of $138 \pm 8.5$ Ma for emplacement of one of the isometric body.

6. The two principal trends of the dykes, together with their absolute age, strongly suggest that their emplacement was controlled by stresses associated with Lower Cretaceous break-up of Gondwana, involving dextral offset of Madagascar with respect to mainland Africa. These stresses reactivated bounding faults to the Karoo graben hosting the kimberlites. Dextral shearing along the bounding faults produced Riedel fractures within the graben that were infilled by kimberlite dykes.

7. The northern Mozambique kimberlites form the NE extremity of a transcontinental NE-SW kimberlite corridor that stretches from southern Namibia across Botswana and central Zimbabwe into northern Mozambique.

8. Insufficient mineral-chemistry was undertaken to establish whether any of the kimberlites are likely to be diamondiferous. No G10 garnets were identified although analysed G9 garnets plot very close to the G10 field and with a trend that warrants future laboratory work. Similarly the few chromite grains that were analysed by the SEM plot close to the field of chromite associated with diamondiferous kimberlites on a $\mathrm{Cr}_{2} \mathrm{O}_{3}$ vs. $\mathrm{MgO}$ diagram, to again warrant more analytical work. Primitive kimberlites (with abundant olivine macrocrysts that are not heavily corroded or altered) as well as evolved kimberlites were sampled which is an encouraging sign for their prospectivity 
for diamonds. A general rule for Group 1 kimberlites is that the dykes associated with diamondiferous pipes are often barren and the aim of any future prospecting has to be to find more isometric bodies, possibly representing pipes. The possibility exists that the kimberlites were generated in a Paleoproterozoic fertile lithosphere. It can therefore be concluded that more exploration for diamondiferous kimberlites is warranted throughout the whole area of the Karoo graben in northern Mozambique and adjacent parts of southern Tanzania.

\section{Acknowledgements}

Dr Key publishes with the permission of the Chief executive of BGS (NERC). Dr Barry Dawson is thanked for reviewing an earlier version of this paper. This work has been carried out as part of the Mineral Resources Management Capacity Building Project, Ministry of Mineral Resources of Mozambique, funded by the Nordic Development Fund and implemented by a team from the Geological Survey of Norway (NGU), the British Geological Survey and the National Directorate of Geology of Mozambique (DNG).

\section{References}

Afonso, RS \& Marques, JM. 1993. Recursos Minerais da República de Moçambique. Instituto de Investigação Científica Trópical - Centro de Geologia, Lisboa. Direcção Nacional de Geologia, Maputo.

Boyd, F.R. 1973. A pyroxene geotherm. Geochimica Cosmochimica Acta, 37, 25332546.

Clement, CR. 1982. A comparative geological study of some major kimberlite pipes in the Northern Cape and Orange Free State. PhD thesis. University of Cape Town. South Africa. 
Cloos, E. 1955. Experimental analysis of fracture patterns. Bulletin, Geological Society of America, 66, 241-256.

Crockett, R.N. \& Mason, R. 1968. Foci of mantle disturbance in southern Africa and their economic significance. Economic Geology, 63, 532-540.

Dawson, J.B. 1980. Kimberlites and their xenoliths. Springer-Verlag, Berlin. 252p.

De Boorder, H. 1982. Deep-reaching fracture zones in the crystalline basement surrounding the West Congo System and their control on mineralization in Angola and Gabon. Geoexploration, 20, 259-273.

Delvaux, D. 2001. Tectonic and palaeostress evolution of the Tanganyika-RukwaMalawi rift segment, East African rift system. In: (eds: PA Zeigler, W Cavazza, AHF Robertson \& SS Crasquin) Peri-Tethys memoir 6; Peri-Tethyan rift/wrench basins and passive margins. Memoires du Museum National d'Histoire Naturelle, 186, 545566.

Ebinger, C, Djomani, YP, Mbede, E, Foster, A \& Dawson, JB. 1997. Rifting Archaean lithosphere: the Eyasi-Manyara-Natron rifts, East Africa. Journal, Geological Society of London, 154, 947-961.

Garvie, OG \& Robinson, DN. 1982. The mineralogy, structure and mode of formation of kelyphitic and associated sub-kelyphitic surfaces on pyrope from kimberlite. Terra Cognita, 2, 229-230.

Griffin, WL \& Ryan, CG. 1995. Trace elements in indicator minerals: area selection and target evaluation in diamond exploration. Journal of Geochemical Exploration, 53, 311-337.

Gurney, JJ \& Zweistra, P. 1995. The interpretation of the major element compositions of mantle minerals in diamond exploration. Journal of Geochemical Exploration, 53, 293-309. 
Jakovenko \& others, 1979. Unpublished report to the DNG. Maputo.

Jelsma, HA, de Wit, MJ, Thiart, C, Dirks, PHGM, Viola, G, Basson, IJ \& Anckar, E. 2004. Preferential distribution along transcontinental corridors of kimberlites and related rocks of Southern Africa. South African Journal of Geology, 107, 301-324.

Karakoulov, AR. 1983. Relatório sobre os trabalhos de prospeccão realizados em 1982 na Bacia do rio Lunho. DNG Library, 1229. Maputo.

Karakoulov, AR. 1984. Relatório sobre os trabalhos de pesquisa de kimberlitos executados nas Bacias dos rios Lunho e Fúgòe, distrito do Lago, provínca do Niassa. DNG Library, 1273. Maputo.

Kirkley, MB, Gurney, JJ \& Levinson, AA. 1991. Age, origin, and emplacement of diamonds: scientific advances in the last decade. Gems \& Gemology, 27 (1), 2-25.

Lächelt, S. 2004. The geology and mineral resources of Mozambique. Direcção Nacional de Geologia, Moçambique.

McKinlay, A.C.M. 1955. Kimberlite intrusions cutting Karoo sediments in the Ruhuhu depression of south-west Tanganyika. Records, Geological Survey of Tanganyika, V, 63-80.

Mitchell, RH. 1986. Kimberlites: mineralogy, geochemistry, and petrology. Plenum Press, New York. 442p.

Nixon, P.H. \& Boyd, F.R. 1973. Petrogenesis of the granular and sheared ultrabasic nodule suite in kimberlite. In: Nixon, PH (editor) Lesotho kimberlites. Lesotho National Development Company, Maseru, 67-75.

Nyblade, AA \& Brazier, RA. 2002. Precambrian lithospheric controls on the development of the East African rift system. Geology, 30, 755-758.

Oberreuter, P \& Pilale, D. 1998. The kimberlitic occurrences in Mozambique: the first discoveries in Nyassa Province. DNG Report, 2322. 
Ramsay, JG \& Huber, MI. 1987. The techniques of modern structural geology, volume 2: Folds and Fractures. Academic Press, London. 77p.

Ryan, C.G. \& Griffin, W.L. 1996. Garnet geotherms: pressure-temperature data from Cr-pyrope garnet xenocrysts in volcanic rocks. Journal of Geophysical Research, 101 (B3), 5611-5625.

Saranga, IS. 2004. Unpublished report to the DNG, Maputo, Mozambique.

Skinner, EMW. 1989. Contrasting Group 1 and II kimberlite petrology: towards a genetic model for kimberlites. In: Ross \& others, Vol1, 528-544.

Smith, CB, Gurney, JJ, Skinner, EMW, Clement, CR \& Ebrahim, N. 1985 Geochemical character of soute4rn African kimberlites: a new approach based on isotopic constraints. Transactions, Geological Society of South Africa, 88, 267-280. Stajilo-Alekseev, K. 1983. Results of the works on diamonds collected from the Basins of the Lunho and Fúgòe rivers during 1982 and 1983. DNG Report, 1273.

Vearncombe, S \& Vearncombe, JR. 2002. Tectonic controls on kimberlite location, southern Africa. Journal of Structural Geology, 24(10), 1619-1625.

Verniers, J, Jourdan, PP, Paulis, RV, Frasca-Spada, L \& De Bock, FR. 1989. The Karroo Graben of Metangula, northern Mozambique. Journal of African Earth Sciences, 9, 137-158.

White, SH, Boorder, H de \& Smith, CB. 1995. Structural controls of kimberlites and lamproite emplacement. Journal of Geochemical Exploration, 53, 245-264. 


\section{List of Figures}

1. Location of the Karoo Graben in Northern Mozambique with bounding faults and major internal faults shown in thick lines. R1 and R2 refer to Riedel shear trends associated with the two main trends of the kimberlite dykes.

2. The distribution of the known kimberlite dykes and pipes within the Lunho River Graben.

3. Distribution of kimberlites in southern Africa that highlights the importance of trans-continental NE-SW kimberlite corridors parallel to the Southern Trans Africa Shear System (STASS). Modified from Jelsma \& others (2004).

4. A plot of $\mathrm{CaO}$ against $\mathrm{Cr}_{2} \mathrm{O}_{3}$ from analysed pyrope garnets. The analysed garnets (square dots) show a very typical kimberlite trend parallel to the G9/G10 boundary line.

5. A plot of Cr2O3 against $\mathrm{MgO}$ in chromites from kimberlites in the Rio Lunho Graben.

6. Plots of spinel analyses from the Lunho River kimberlites.

7. A plot of $\mathrm{MgO}$ against $\mathrm{FeO}$ for analysed olivine grains from the Lunho River kimberlites.

8. Rb-Sr isochron plot of phlogopite analyses.

\section{List of Tables.}

1. (a) Four whole rock analyses (major elements) of Lunho River Graben kimberlites compared to two uncontaminated kimberlite samples shown in Mitchell (1986) and average values for southern African kimberlites from Smith \& others (1985). (b) Minor and trace element analyses of Northern Mozambique kimberlites with average analyses of southern African kimberlites taken from Smith \& others (1985). Values in ppm. 
2. Olivine and pyroxene partial SEM analyses from Lunho River Graben kimberlites.

3. SEM analyses of pyrope grains from Lunho River Graben kimberlites.

4. SEM analyses of mica flakes from Lunho River Graben kimberlites.

5. Rb-Sr data on phlogopites used in determining the absolute age of kimberlite emplacement 


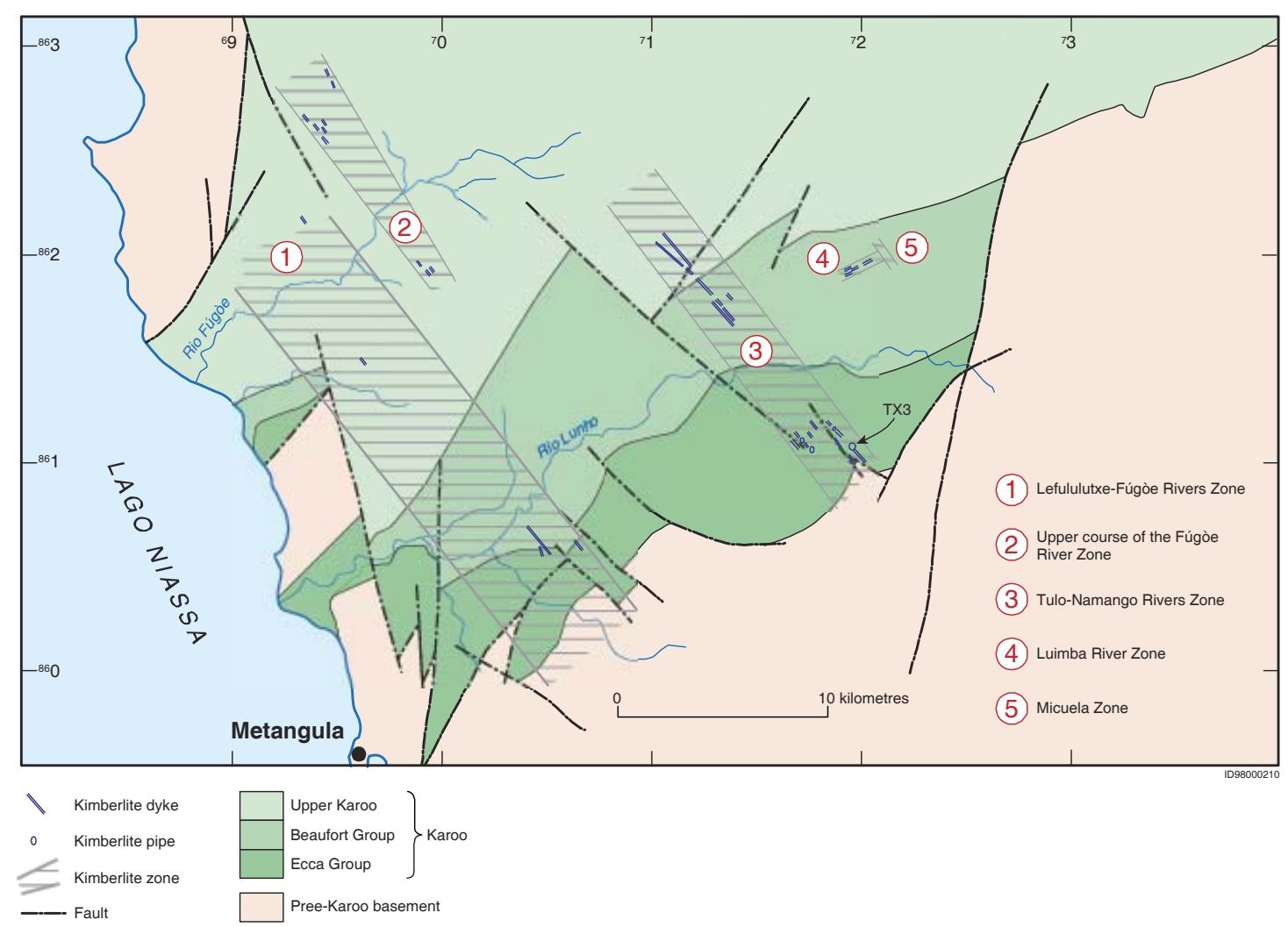

Figure 2. The location of the kimberlite dykes and pipes as well as the five zones of kimberlite emplacement recognised by the original Soviet work. 
Kimberlites of northern Mozambique by Key \& others 


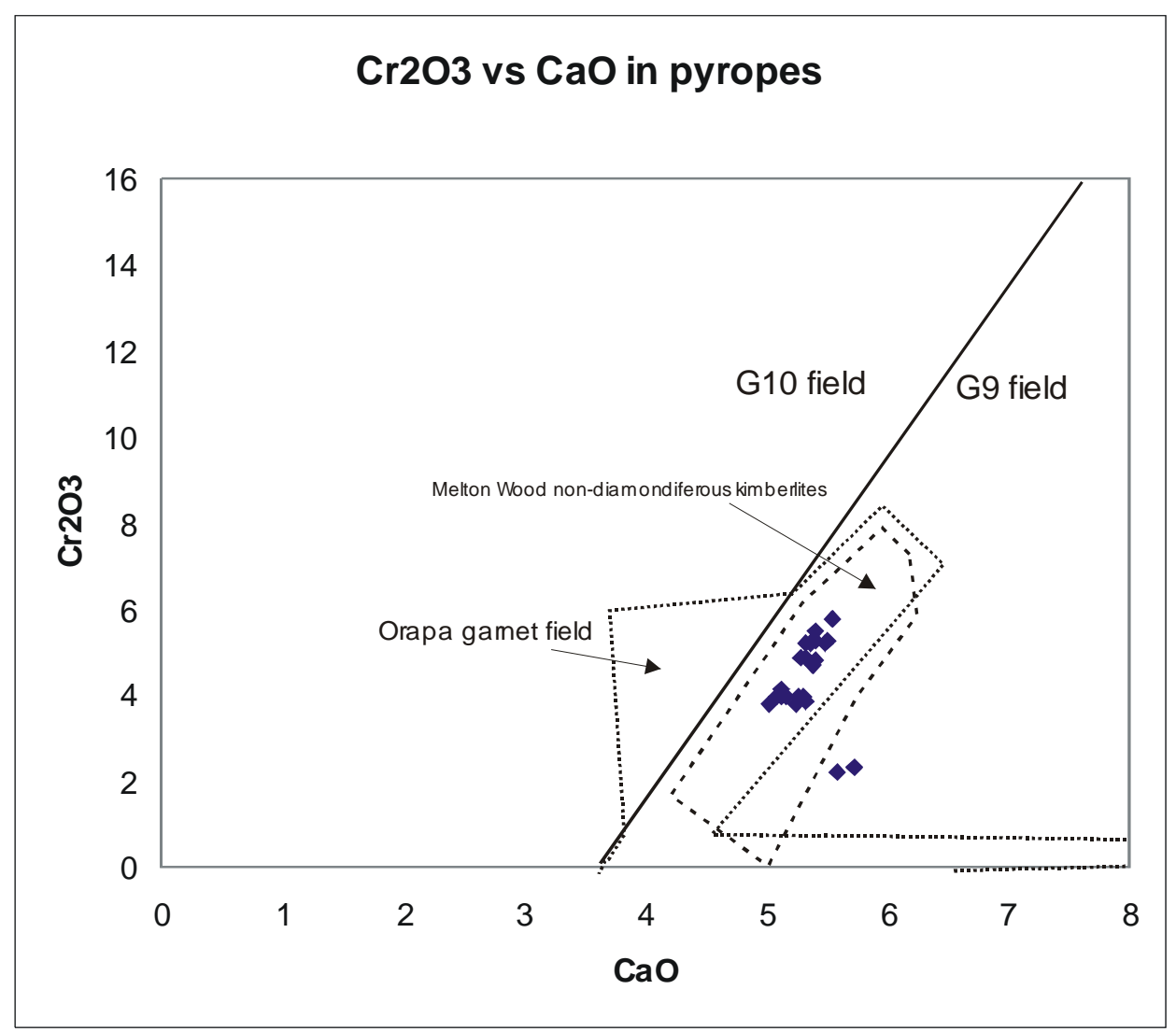

Figure 4. A plot of $\mathrm{CaO}$ against $\mathrm{Cr}_{2} \mathrm{O}_{3}$ from analysed pyrope garnets. The analysed garnets (square dots) show a very typical kimberlite trend parallel to the G9/G10 boundary line.

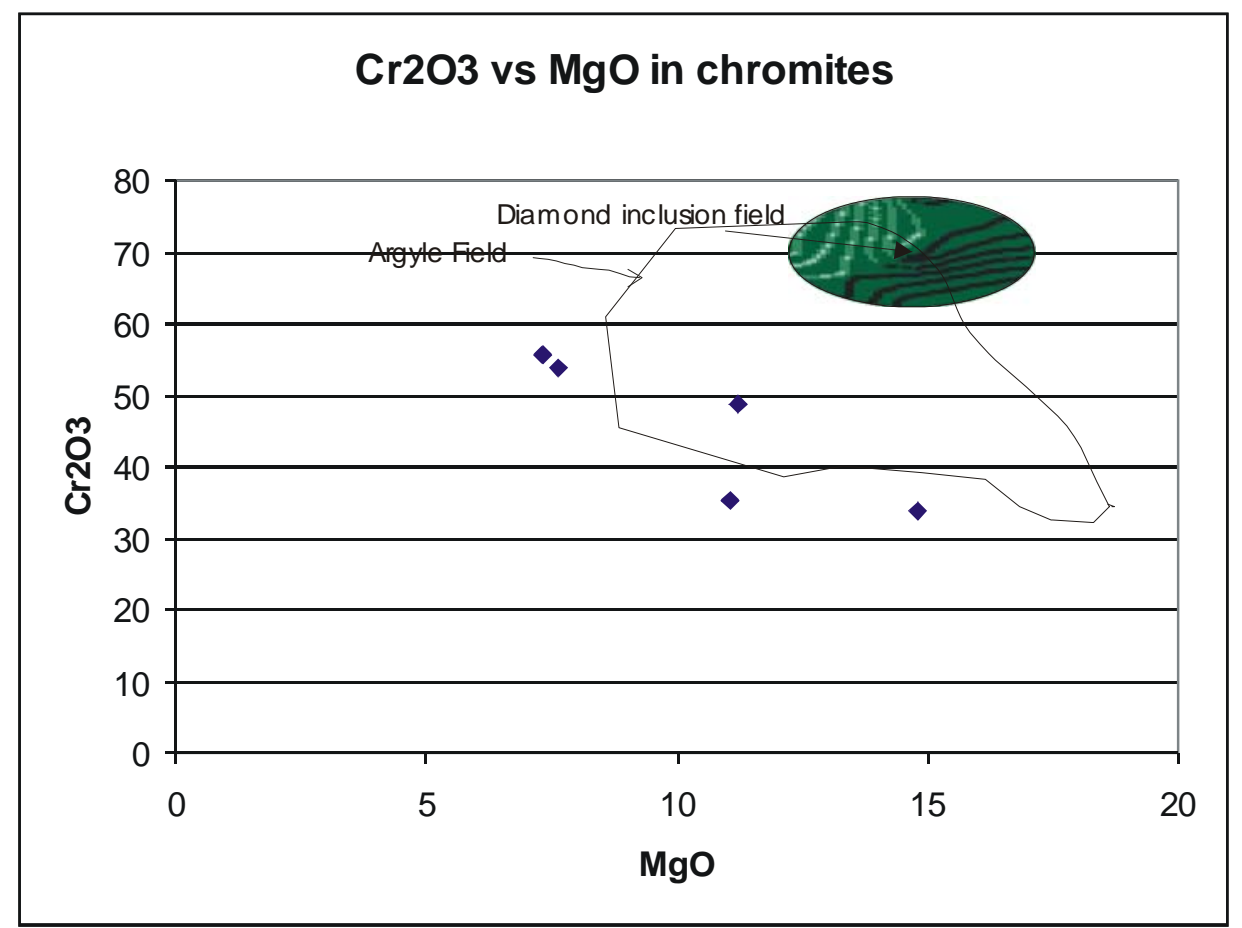

Figure 5. A plot of $\mathrm{Cr}_{2} \mathrm{O}_{3}$ against $\mathrm{MgO}$ for chromites from Lunho River Graben kimberlites 

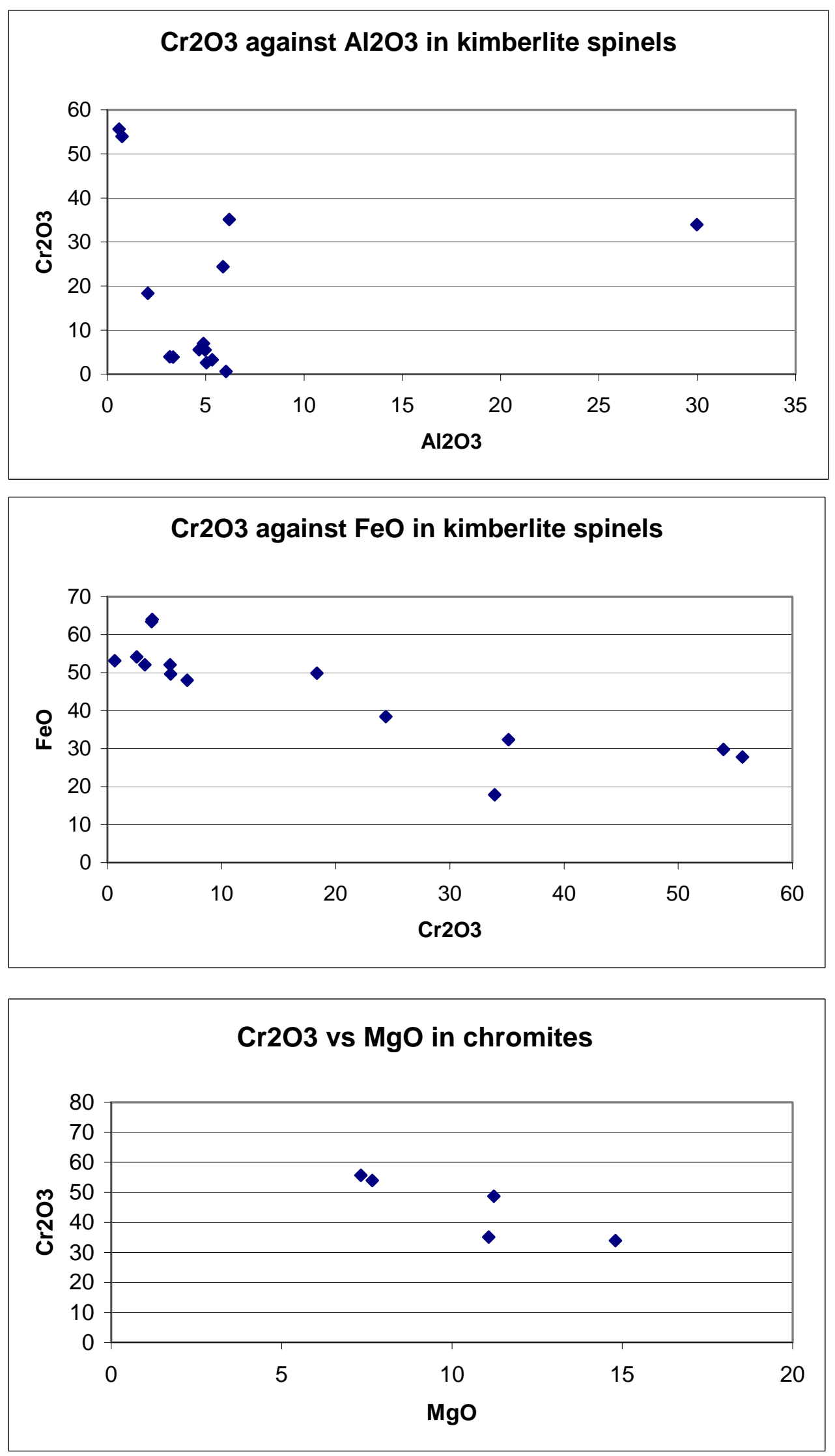

Figure 6. Plots of spinel analyses from the Lunho River kimberlites. 


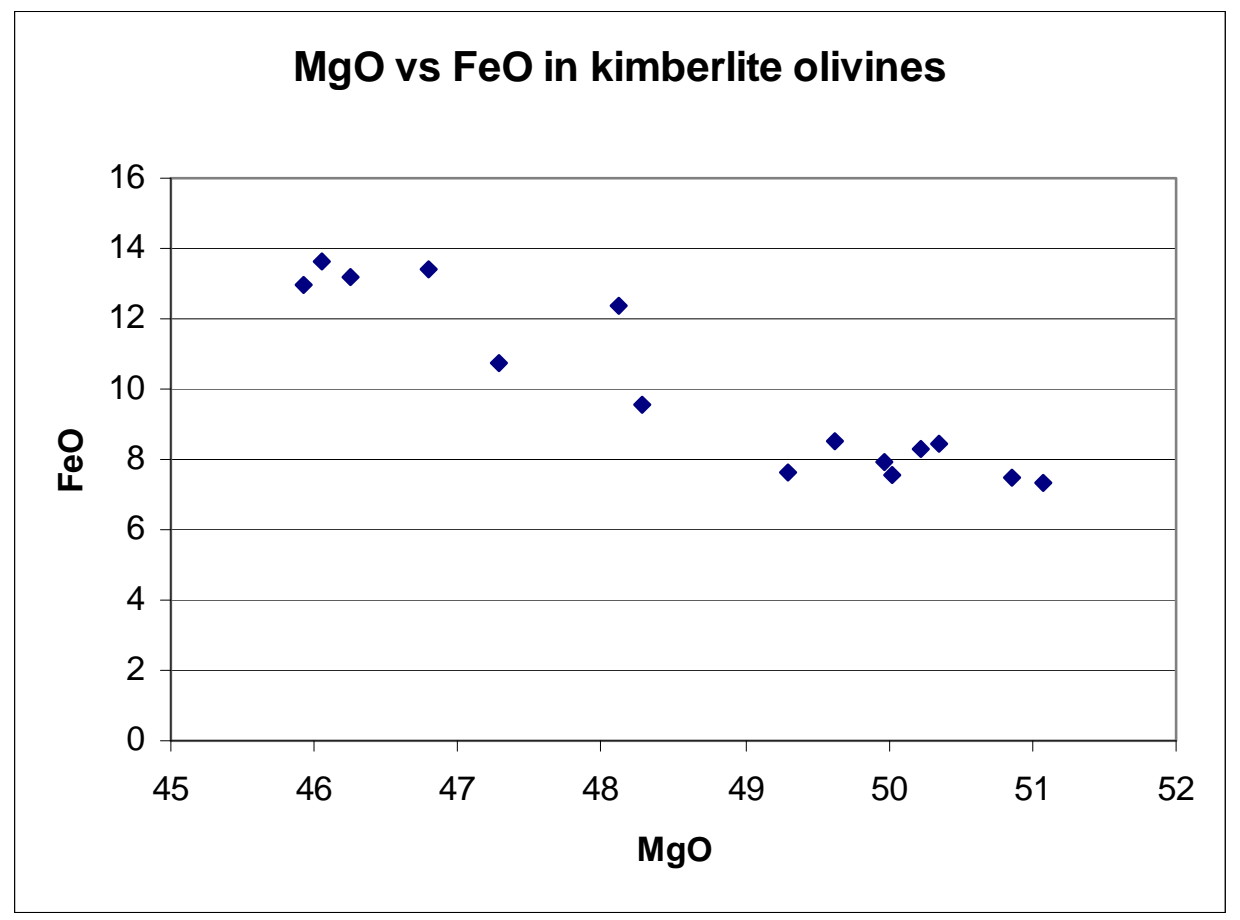

Figure 7. A plot of $\mathrm{MgO}$ against $\mathrm{FeO}$ for analysed olivine grains from the Lunho River kimberlites. 
Fig. 8

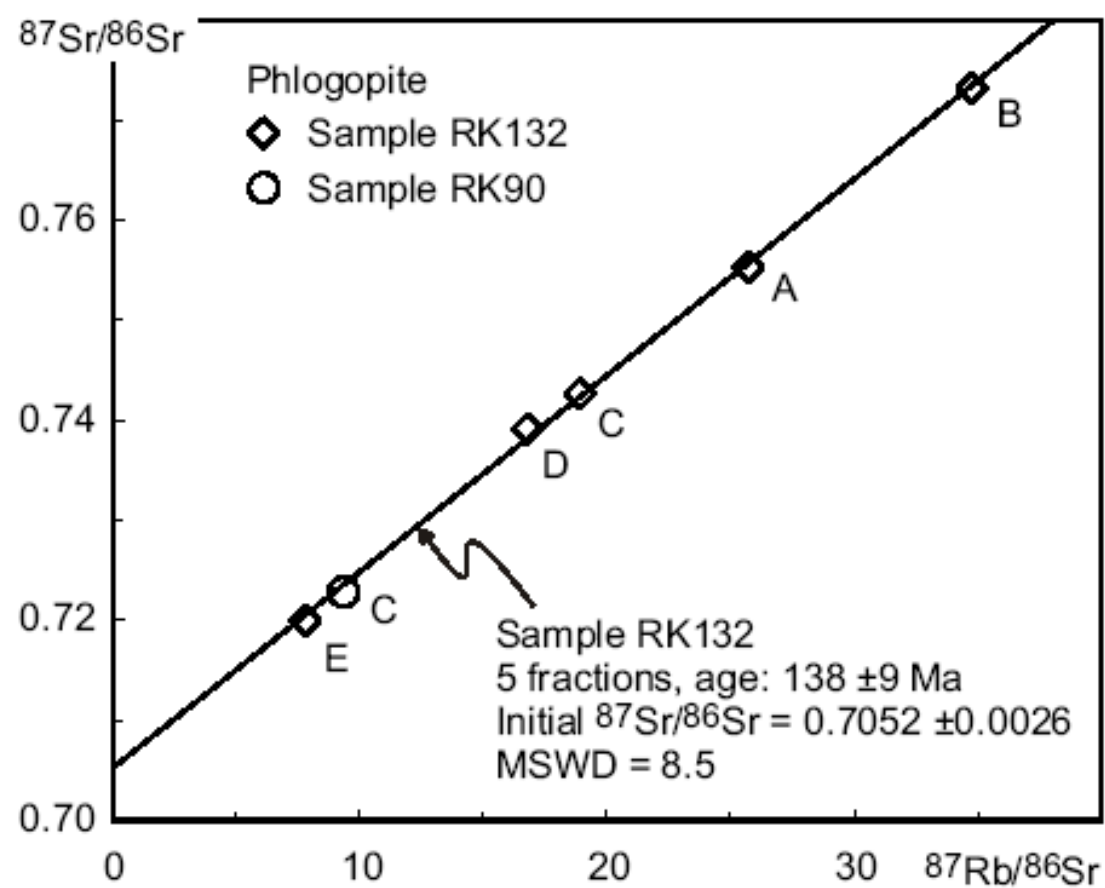




\begin{tabular}{|c|c|c|c|c|c|c|c|c|c|}
\hline Sample & $\begin{array}{l}\text { Uncor } \\
\text { kimbe } \\
\text { (Mitch }\end{array}$ & $\begin{array}{l}\text { taminated } \\
\text { lites } \\
\text { ll, 1986) }\end{array}$ & 31989 & 31991 & 31988 & 31990 & $\begin{array}{l}\text { Group } \\
\text { Ib }\end{array}$ & $\begin{array}{l}\text { Group } \\
\text { la }\end{array}$ & $\begin{array}{l}\text { Group } \\
\text { II }\end{array}$ \\
\hline $\mathrm{SiO}_{2}$ & 30.4 & 33.78 & 29.23 & 27.76 & 9.14 & 21.34 & 25.7 & 32.1 & 36.3 \\
\hline $\mathrm{TiO}_{2}$ & 0.9 & 1.4 & 3.78 & 2.1 & 2.9 & 3.7 & 3.0 & 2.0 & 1.0 \\
\hline $\mathrm{Al}_{2} \mathrm{O}_{3}$ & 1.9 & 2.27 & 2.27 & 1.94 & 2.09 & 2.44 & 3.1 & 2.6 & 3.2 \\
\hline $\mathrm{Cr}_{2} \mathrm{O}_{3}$ & 0.14 & 0.28 & 0.11 & 0.11 & 0.07 & 0.08 & & & \\
\hline $\mathrm{Fe}_{2} \mathrm{O}_{3}$ & 4 & 7.81 & 115 & a. 57 & 737 & & & 92 & \\
\hline $\mathrm{FeO}$ & 2 & 1.62 & 11.5 & 9.51 & 1.31 & 7.41 & 12.7 & 9.2 & 8.4 \\
\hline $\mathrm{MnO}$ & 0.13 & 0.18 & 0.16 & 0.16 & 1.05 & 1.02 & 0.2 & 0.2 & 0.2 \\
\hline $\mathrm{MgO}$ & 25.9 & 32.13 & 28.22 & 27.73 & 8.04 & 5.61 & 23.8 & 28.5 & 29.7 \\
\hline $\mathrm{CaO}$ & 14.8 & 5.41 & 9.11 & 11.82 & 32.65 & 28.47 & 14.1 & 8.2 & 6.0 \\
\hline $\mathrm{Na}_{2} \mathrm{O}$ & 0.04 & 0.11 & $<0.1$ & $<0.1$ & $<0.1$ & $<0.1$ & 0.2 & 0.2 & 0.1 \\
\hline $\mathrm{K}_{2} \mathrm{O}$ & 0.29 & 0.33 & 1.58 & 1.17 & 0.22 & 0.28 & 0.6 & 1.1 & 3.2 \\
\hline$P_{2} O_{5}$ & 0.35 & 0.69 & 0.55 & 1.34 & 0.7 & 0.69 & 1.1 & 1.1 & 1.1 \\
\hline LOI & 19.1 & 14.09 & 11.54 & 13.56 & 32.53 & 26.03 & 16.3 & 14 & 9.6 \\
\hline Total & 99.95 & 100.1 & 97.93 & 97.13 & 96.53 & 96.87 & 100.8 & 99.2 & 98.8 \\
\hline $\mathrm{Cl}$ & 1.22 & 1.10 & 1.00 & 0.99 & 1.32 & 3.85 & & & \\
\hline
\end{tabular}

Table 1a. Four whole rock analyses (major elements) of Lunho River Graben kimberlites compared to two uncontaminated kimberlite samples shown in Mitchell (1986) and the mean analyses from uncontaminated southern African kimberlites from Smith \& others (1985). 


\begin{tabular}{|c|c|c|c|c|c|c|c|}
\hline Sample & $\begin{array}{l}\text { Group la (Smith } \\
\text { \& others, 1985) }\end{array}$ & $\begin{array}{l}\text { Group Ib (Smith } \\
\text { \& others, 1985) }\end{array}$ & $\begin{array}{l}\text { Group II (Smith \& } \\
\text { others, 1985) }\end{array}$ & 31989 & 31991 & 31988 & 31990 \\
\hline $\mathrm{Nb}$ & 165 & 210 & 120 & 113 & 123 & 94 & 117 \\
\hline $\mathrm{Zr}$ & 200 & 385 & 290 & 381 & 330 & 389 & 415 \\
\hline $\mathrm{Y}$ & 13 & 30 & 16 & 14 & 21 & 12 & 16 \\
\hline $\mathrm{Sr}$ & 825 & 1020 & 1140 & 792 & 1790 & 1174 & 862 \\
\hline $\mathrm{Rb}$ & 50 & 30 & 135 & 65 & 51 & 9 & 15 \\
\hline $\mathrm{U}$ & 4 & 6 & 5 & $<10$ & $<10$ & $<10$ & $<10$ \\
\hline Th & 18 & 27 & 30 & 14 & 13 & 11 & 12 \\
\hline $\mathrm{Pb}$ & 7 & 10 & 30 & $<10$ & $<10$ & $<10$ & $<10$ \\
\hline $\mathrm{Cr}$ & 1400 & 1000 & 1800 & 1127 & 1115 & 681 & 864 \\
\hline V & 75 & 170 & 85 & 151 & 178 & 132 & 138 \\
\hline Sc & 13 & 20 & 20 & 27 & 25 & 44 & 43 \\
\hline $\mathrm{Hf}$ & Not determined & Not determined & Not determined & 23 & 28 & 16 & 20 \\
\hline $\mathrm{Ba}$ & 1000 & 850 & 3000 & 730 & 1678 & 468 & 358 \\
\hline $\mathrm{Ga}$ & 4 & 8 & 6 & $<10$ & $<10$ & $<10$ & $<10$ \\
\hline $\mathrm{Zn}$ & 56 & 75 & 60 & 73 & 70 & 60 & 73 \\
\hline $\mathrm{Cu}$ & 54 & 79 & 30 & 53 & 47 & 48 & 63 \\
\hline $\mathrm{Ni}$ & 1360 & 800 & 1400 & 1089 & 1067 & 825 & 1147 \\
\hline Co & 83 & 79 & 85 & 96 & 74 & 54 & 76 \\
\hline $\mathrm{Ce}$ & 140 & 220 & 350 & 76 & 258 & 145 & 188 \\
\hline $\mathrm{La}$ & 90 & 125 & 200 & 61 & 136 & 53 & 78 \\
\hline Nd & 90 & 100 & 145 & 43 & 103 & 64 & 88 \\
\hline
\end{tabular}

Table 1b. Minor and trace element analyses of Northern Mozambique kimberlites with average analyses of southern African kimberlites taken from Smith \& others (1985). Values in ppm. 


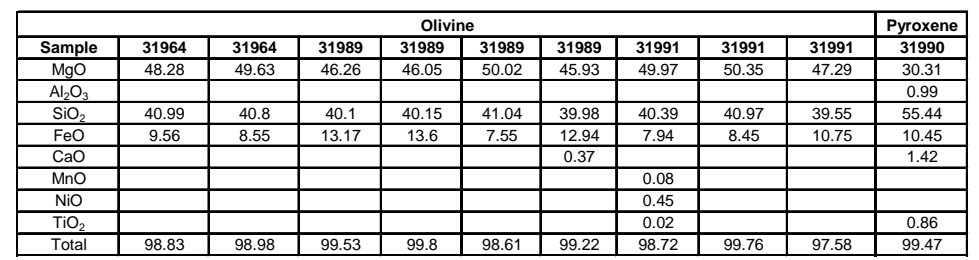

Table 2. Representative partial SEM analyses of olivine and pyroxene (enstatite inclusion in Mg-ilmenite) grains from Lunho River Graben kimberlites.

\begin{tabular}{|c|c|c|c|c|c|c|c|c|c|c|}
\hline \multicolumn{90}{|c|}{ PYROPE } \\
\hline Sample & $\mathbf{3 1 9 8 6}$ & $\mathbf{3 1 9 8 6}$ & $\mathbf{3 1 9 8 6}$ & $\mathbf{3 1 9 8 6}$ & $\mathbf{3 1 9 8 4}$ & $\mathbf{3 1 9 8 4}$ & $\mathbf{3 1 9 8 4}$ & $\mathbf{3 1 9 8 4}$ & $\mathbf{3 1 9 9 1}$ & $\mathbf{3 1 9 9 1}$ \\
\hline $\mathrm{MgO}$ & 20.01 & 20.25 & 20.39 & 20.5 & 20.43 & 20.44 & 20.37 & 20.32 & 19.62 & 19.68 \\
\hline $\mathrm{Al}_{2} \mathrm{O}_{3}$ & 18.77 & 18.88 & 19.01 & 19.37 & 20.31 & 20.23 & 20 & 20.21 & 20.96 & 21.1 \\
\hline $\mathrm{SiO}_{2}$ & 41.28 & 41.26 & 41.76 & 41.21 & 41.63 & 41.77 & 42.09 & 41.8 & 41.14 & 41.12 \\
\hline $\mathrm{CaO}$ & 5.54 & 5.37 & 5.28 & 5.38 & 5.24 & 5.31 & 5.33 & 5.08 & 5.59 & 5.73 \\
\hline $\mathrm{Cr}_{2} \mathrm{O}_{3}$ & 5.75 & 5.19 & 4.89 & 4.69 & 3.8 & 3.97 & 3.83 & 3.98 & 2.23 & 2.32 \\
\hline $\mathrm{TiO}_{2}$ & 0.46 & 0.58 & 0.48 & 0.32 & 0.13 & 0.02 & 0.22 & 0.36 & & \\
\hline $\mathrm{MnO}$ & 0.4 & 0.32 & 0.24 & 0.3 & 0.39 & 0.32 & 0.36 & 0.51 & & \\
\hline $\mathrm{FeO}$ & 7.46 & 7.34 & 7.42 & 6.57 & 7.12 & 7.28 & 7.2 & 7.15 & 9.31 & 8.85 \\
\hline $\mathrm{Total}$ & 99.66 & 99.19 & 99.47 & 98.34 & 99.06 & 99.35 & 99.4 & 99.41 & 98.85 & 98.81 \\
\hline
\end{tabular}

Table 3. SEM partial analyses of pyrope grains from Lunho River Graben kimberlites

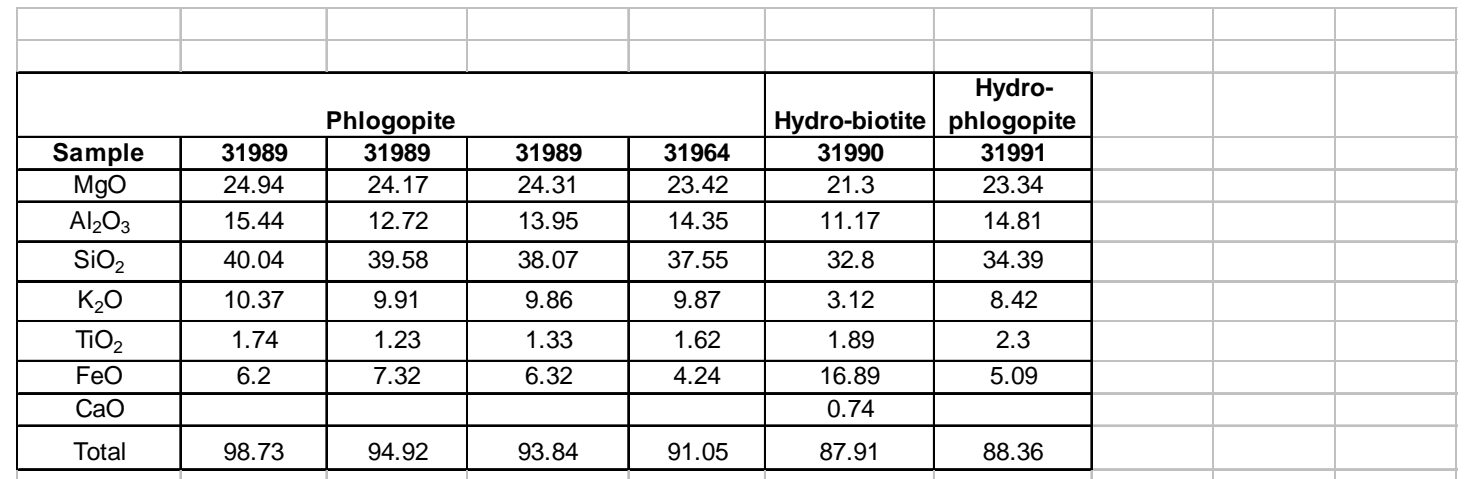

Table 4. Partial SEM analyses of mica flakes from Rio Lunho Graben kimberlites.

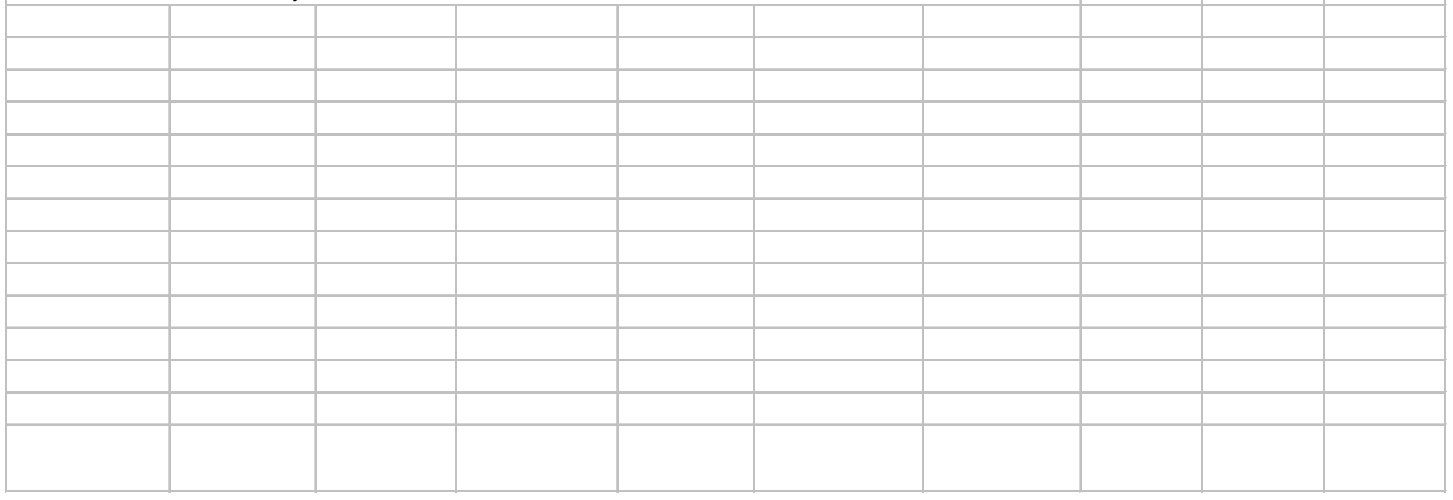


Table 5. Rb-Sr isotopic data on phlogopite

\begin{tabular}{|lccccc|}
\hline & $\mathrm{Rb}$ & $\mathrm{Sr}$ & ${ }^{87} \mathrm{Rb}$ & ${ }^{87} \mathrm{Sr}$ & $\pm 2 \sigma$ \\
\hline & $(\mathrm{ppm})$ & $(\mathrm{ppm})$ & ${ }^{86} \mathrm{Sr}$ & ${ }^{86} \mathrm{Sr}$ & \\
\hline & & & & & \\
\hline RK90C & 538.6 & 167.3 & 9.332 & 0.722813 & 0.000016 \\
\hline RK132A & 355.2 & 40.14 & 25.73 & 0.755273 & 0.000018 \\
\hline RK132B & 475.1 & 39.80 & 34.77 & 0.773168 & 0.000017 \\
\hline RK132C & 349.2 & 53.62 & 18.91 & 0.742625 & 0.000016 \\
\hline RK132D & 335.1 & 57.89 & 16.80 & 0.739124 & 0.000026 \\
\hline RK132E & 343.9 & 127.7 & 7.800 & 0.719923 & 0.000015 \\
\hline
\end{tabular}




\section{List of Plates}

1. Fresh kimberlite sample taken from GR 36L 07194908610422 with a large rounded pyrope xenocryst set in a blue-grey massive hypabyssal kimberlite groundmass. Diameter of coin is approximately $2.5 \mathrm{~cm}$.

2. Indurated Karoo sandstone clasts in hypabyssal kimberlite from GR 36L 0719490 8610422. Diameter of coin is approximately $2.5 \mathrm{~cm}$.

3. Photomicrograph P2050081 of sample 31986 showing a rounded pyrope garnet xenocryst that was analysed by the SEM (Table 5). Decompression cracks in the garnet are partly infilled by secondary phases that include cryptocrystalline aggregates from the kelyphitic rim. X2.5 objective with 1mm E-W length to field of view.

4. Separated phlogopite flakes used to date the kimberlites (Figure 8). 